\title{
Research on environmental accounting information disclosure in public companies
}

\author{
Yan Lin \\ Department of Accounting ,Hebei Financa University,Baoding,China
}

\begin{abstract}
Traditional financial accounting is lack of measurement of enterprise environmental resources, environmental liability and environmental costs and confirmation of business environmental gains or losses. The development of environmental accounting and establishment of environmental information disclosure system is imperative. Therefore, data of eight large pollution industries 32 public companies from 2008 to 2013 are selected. Then current situation of environmental accounting information disclosure in public companies is analyzed from two aspects which are prospectus and annual reports. Existing problems and their causes are studied deeply. Some suggestions for perfecting the environmental accounting information disclosure system in listed companies are put forward finally.
\end{abstract}

Keywords: Public company; environmental accounting; information disclosure

\section{Introduction}

Environmental accounting is accounting and environment science and technology of combining an edge applications disciplines in accounting system and it includes environmental economics, system science, and other multiple disciplines. In order to solve the increasingly serious environmental problems, environmental accounting provides a full range of viewpoints and deep theoretical support. There is a big difference between environmental accounting and traditional accounting. Traditional accounting focuses on enterprise's economic information and basically reflects enterprise's economic accountability.

Therefore, further research on environmental accounting information disclosure will build a defense line of development of green economy in China. What is more, it can cultivate more enterprises that are in line with international environmental standards to develop overseas business.

\section{Present situations of environmental accounting in- formation disclosure in public company}

\subsection{Sample selection and data sources}

Data of eight large pollution industries 32 public companies from 2008 to 2013 are selected as samples. Eight big polluting industries are mainly metallurgy, mining, electricity, chemical fiber industry, pharmaceutical industry, chemical industry, paper industry and textile industry. Thirty-two public companies of these eight big pollution industries are chose. Information of environmental accounting information disclosure is obtained by reading the prospectus and company annual reports of listed companies from the China securities regulatory commission official website tide of information network.

\subsection{Environmental accounting information disclosure present situations in public companies}

Current situation of environmental accounting information disclosure in public companies is analyzed from two aspects which are prospectus and annual reports.

(1)Status analysis of environmental accounting information disclosure in prospectus

With referring to thirty-two listed companies' prospectus, analysis and induction of accounting information disclosure content are carried on from qualitative description and quantitative disclosure two aspects, as shown in table 1, table 2 and table 3 .

Table 1 Thirty-two companies' information disclosure status from the perspective of industry

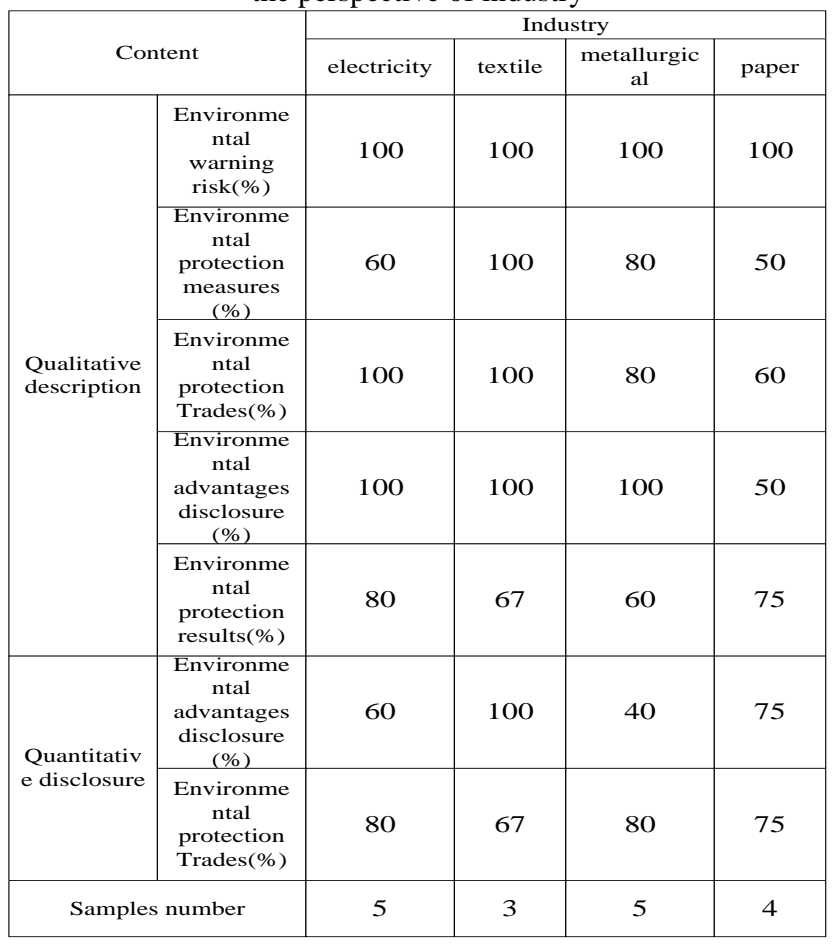


Table 2 Thirty-two companies' information disclosure status from the perspective of industry (continue table)

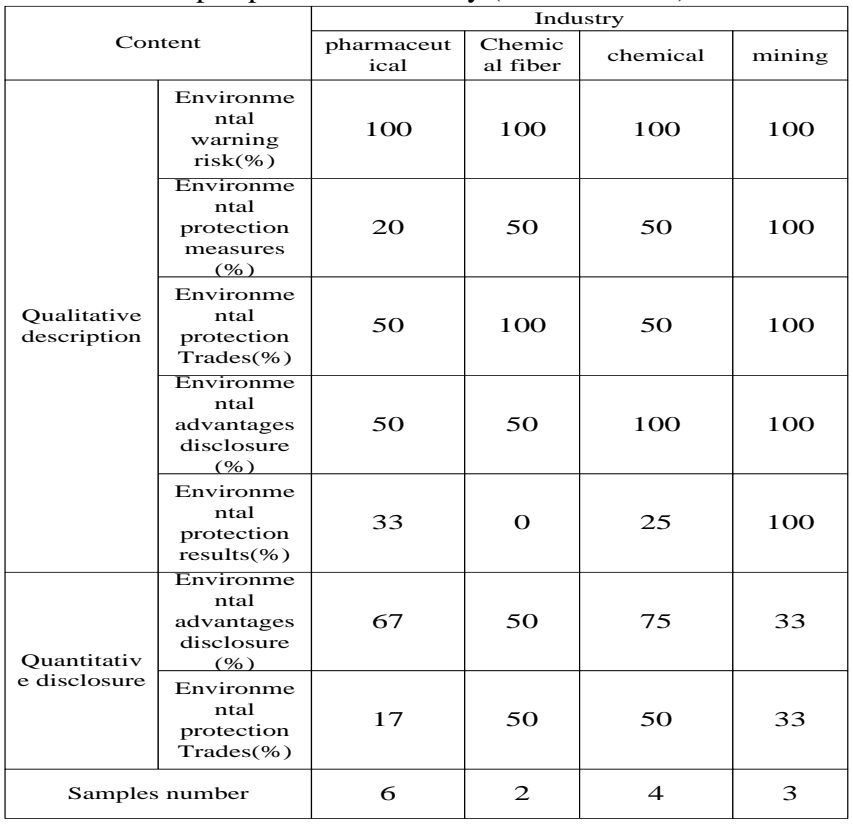

Table3 Thirty-two companies' information disclosure status from the perspective of year

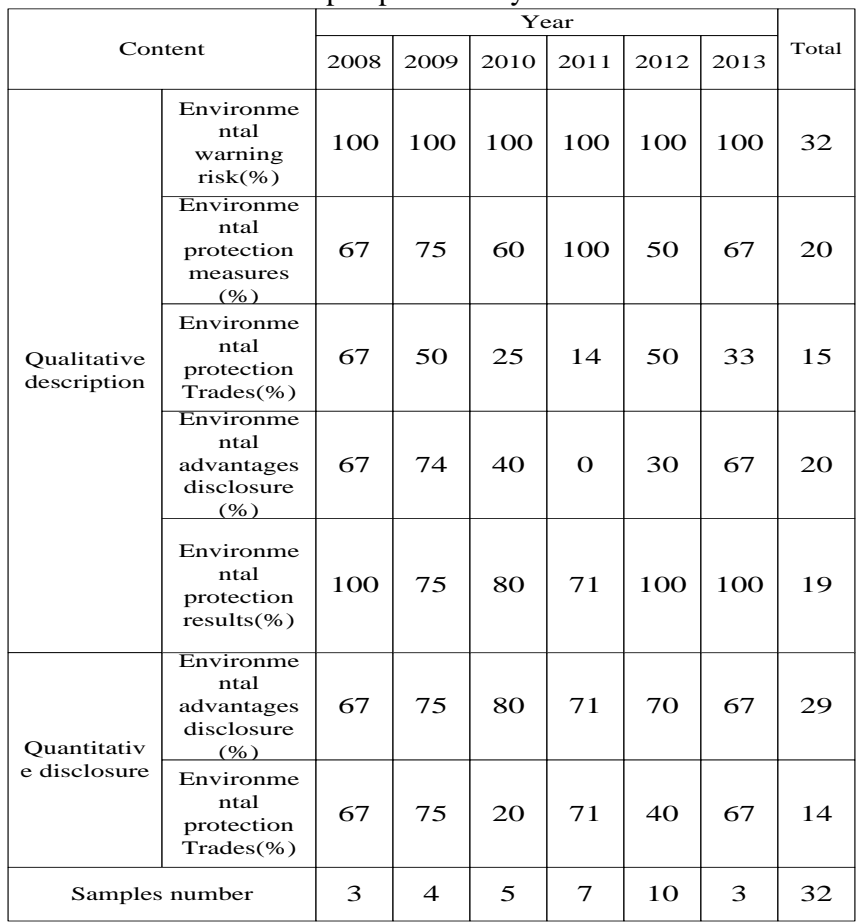

(2)Status analysis of environmental accounting information disclosure in annual reports

By consulting and analyzing thirty-two companies' annual accounting reports, environmental accounting information evaluation indexes are mainly concentrated in three parts that are occurrence of major environmental problems and environmental risks, environmental laws compliance situation, environmental management situation, as shown in table 4and table 5.

Table4 Environmental accounting information disclosed by public companies

\begin{tabular}{|c|c|c|c|c|c|}
\hline \multicolumn{2}{|c|}{ Content } & $\begin{array}{l}\text { Metallur } \\
\text { gical }\end{array}$ & $\begin{array}{l}\text { Mini } \\
\mathrm{ng}\end{array}$ & $\begin{array}{l}\text { Elect } \\
\text { ricity }\end{array}$ & $\begin{array}{l}\text { Che } \\
\text { mical }\end{array}$ \\
\hline \multirow{4}{*}{$\begin{array}{c}\text { Occurrence of } \\
\text { major } \\
\text { environmental } \\
\text { problems and } \\
\text { environmental } \\
\text { risks }\end{array}$} & $\begin{array}{c}\text { Environmental } \\
\text { accidents } \\
\text { information }\end{array}$ & & & & $\sqrt{ }$ \\
\hline & $\begin{array}{c}\text { Fines and } \\
\text { compensation }\end{array}$ & & $\sqrt{ }$ & & $\sqrt{ }$ \\
\hline & Corrective action & & & & $\sqrt{ }$ \\
\hline & $\begin{array}{c}\text { Environmental } \\
\text { liabilities and } \\
\text { contingencies, } \\
\text { litigation }\end{array}$ & & & & $\sqrt{ }$ \\
\hline \multirow{5}{*}{$\begin{array}{c}\text { Environmental } \\
\text { laws } \\
\text { compliance } \\
\text { situation }\end{array}$} & Exhaust emission & & $\sqrt{ }$ & & \\
\hline & $\begin{array}{l}\text { waste-water } \\
\text { discharges }\end{array}$ & & & & \\
\hline & $\begin{array}{l}\text { Solid waste } \\
\text { disposal }\end{array}$ & & & & \\
\hline & $\begin{array}{c}\text { energy-saving } \\
\text { emission }\end{array}$ & & $\sqrt{ }$ & & \\
\hline & sewage charges & & $\sqrt{ }$ & $\sqrt{ }$ & \\
\hline \multirow{8}{*}{$\begin{array}{c}\text { Environmental } \\
\text { management } \\
\text { situation }\end{array}$} & $\begin{array}{l}\text { Environmental } \\
\text { protection } \\
\text { facilities } \\
\text { construction } \\
\text { operation } \\
\end{array}$ & & & & \\
\hline & $\begin{array}{c}\text { Environmental } \\
\text { impact assessment } \\
\text { of construction } \\
\text { projects }\end{array}$ & & & & \\
\hline & $\begin{array}{c}\text { Environmental } \\
\text { protection concept }\end{array}$ & & & $\sqrt{ }$ & $\sqrt{ }$ \\
\hline & $\begin{array}{l}\text { Goal and plan of } \\
\text { environmental } \\
\text { protection }\end{array}$ & & & $\sqrt{ }$ & \\
\hline & $\begin{array}{l}\text { Environmental } \\
\text { management } \\
\text { system }\end{array}$ & & $\sqrt{ }$ & & \\
\hline & $\begin{array}{c}\text { Environmental } \\
\text { protection honor }\end{array}$ & & $\sqrt{ }$ & & $\sqrt{ }$ \\
\hline & $\begin{array}{l}\text { ISO } 14000 \text { or other } \\
\text { environmental } \\
\text { certification }\end{array}$ & & & $\sqrt{ }$ & \\
\hline & $\begin{array}{l}\text { Environmental } \\
\text { education }\end{array}$ & & & & \\
\hline
\end{tabular}


Table5 Environmental accounting information disclosed by public companies (continue table)

\begin{tabular}{|c|c|c|c|c|c|}
\hline \multicolumn{2}{|c|}{ Content } & $\begin{array}{c}\text { Pharmac } \\
\text { eutical }\end{array}$ & $\begin{array}{l}\text { Chemical } \\
\text { fiber }\end{array}$ & $\underset{\mathrm{r}}{\text { Pape }}$ & $\begin{array}{c}\text { Texti } \\
\text { le }\end{array}$ \\
\hline \multirow{4}{*}{$\begin{array}{c}\text { Occurrence of } \\
\text { major } \\
\text { environmental } \\
\text { problems and } \\
\text { environmental } \\
\text { risks }\end{array}$} & $\begin{array}{l}\text { Environmental } \\
\text { accidents } \\
\text { information }\end{array}$ & & & $\sqrt{ }$ & $\sqrt{ }$ \\
\hline & $\begin{array}{c}\text { Fines and } \\
\text { compensation }\end{array}$ & & & & \\
\hline & Corrective action & & & $\sqrt{ }$ & \\
\hline & $\begin{array}{l}\text { Environmental } \\
\text { liabilities and } \\
\text { contingencies, } \\
\text { litigation }\end{array}$ & & & & \\
\hline \multirow{5}{*}{$\begin{array}{c}\text { Environmental } \\
\text { laws } \\
\text { compliance } \\
\text { situation }\end{array}$} & Exhaust emission & & & $\sqrt{ }$ & \\
\hline & $\begin{array}{l}\text { waste-water } \\
\text { discharges }\end{array}$ & $\sqrt{ }$ & & $\sqrt{ }$ & $\sqrt{ }$ \\
\hline & $\begin{array}{c}\text { Solid waste } \\
\text { disposal }\end{array}$ & & & & \\
\hline & $\begin{array}{c}\text { energy-saving } \\
\text { emission }\end{array}$ & $\sqrt{ }$ & & $\sqrt{ }$ & $\sqrt{ }$ \\
\hline & sewage charges & & & & \\
\hline \multirow{8}{*}{$\begin{array}{l}\text { Environmental } \\
\text { management } \\
\text { situation }\end{array}$} & $\begin{array}{l}\text { Environmental } \\
\text { protection } \\
\text { facilities } \\
\text { construction } \\
\text { operation } \\
\end{array}$ & $\sqrt{ }$ & & & \\
\hline & $\begin{array}{c}\text { Environmental } \\
\text { impact assessment } \\
\text { of construction } \\
\text { projects }\end{array}$ & & & & \\
\hline & $\begin{array}{c}\text { Environmental } \\
\text { protection concept }\end{array}$ & $\sqrt{ }$ & & $\sqrt{ }$ & \\
\hline & $\begin{array}{l}\text { Goal and plan of } \\
\text { environmental } \\
\text { protection }\end{array}$ & & & & \\
\hline & $\begin{array}{c}\text { Environmental } \\
\text { management } \\
\text { system }\end{array}$ & & & & \\
\hline & $\begin{array}{l}\text { Environmental } \\
\text { protection honor }\end{array}$ & $\sqrt{ }$ & $\sqrt{ }$ & & $\sqrt{ }$ \\
\hline & $\begin{array}{l}\text { ISO } 14000 \text { or other } \\
\text { environmental } \\
\text { certification }\end{array}$ & $\sqrt{ }$ & & $\sqrt{ }$ & $\sqrt{ }$ \\
\hline & $\begin{array}{c}\text { Environmental } \\
\text { education }\end{array}$ & & & $\sqrt{ }$ & \\
\hline
\end{tabular}

\subsection{Environmental accounting information disclosure existing problems in public companies}

By referring to prospectus and annual reports of thirtytwo public companies, environmental accounting information disclosure situation is analyzed. It shows that environmental accounting is gradually mature and specific. Compared with foreign companies, there exist many problems as follows.

(1)Environmental accounting information disclosure ratio is not high in general, but it is on the rise. What is more, environmental accounting information ratio of annual report is notably higher than that of prospectus.

(2)Environmental accounting information disclosure mode is single. Many companies basically use supplementary report mode not separate report model. Environment accounting information is simple and single whether meet the requirements of information users.

(3)The content of environmental accounting information disclosure is not standard. Environmental accounting information disclosure content of different enterprises in the same industry in the prospectus and the annual reports are different and lack relevance and reliability. Many companies' environment accounting information disclosure lacks independent audit and relevant institutions identification. Therefore, the reliability of the information may be problematic.

\section{Cause analysis of environmental accounting infor- mation disclosure question}

We can find the reasons for these environmental accounting information disclosure problems mentioned above.

(1)Imperfection of relevant laws and regulations

The relevant laws and regulations of environmental accounting information disclosure are not sound that leads to environmental accounting information disclosure not enough full and specific. A complete set of environmental accounting information disclosure system is not formed and it is lack of operability and comparability. First, establishment of environmental accounting standards is defective. Second, accounting measurement is not clear and it is lack of scientific quantitative method and feasible index system which makes the environment information such as capital and debt, environmental costs and benefits not definite. Third, there is no a clear legal requirements in environmental accounting information disclosure mode.

(2)Lack of government supervision

Owing to shortage of government monitoring environmental consciousness of public companies in our country is poor. Environmental accounting information disclosure consciousness is not strong and thereby disclosure proportion is not high. Definition of relevant government agencies on environmental issues is unclear, namely there is no clear regulation refer to strong pollution enterprise standards and no clear determination of environmental responsibility. Therefore, let many enterprises take advantage.

(3)Lack of environmental accounting information disclosure environment

Moral idea of enterprise environmental responsibility has not been true to form, which will lead to environmental accounting information disclosure lack of the whole society participation. Theory research and practice is not enough mature and the overall level of environmental accounting information disclosure is low actually. With the improvement of whole social environmental protection consciousness, information disclosure is more and more perfect and the number of disclosure enterprise is more and more. 


\section{Suggestions on perfection of environmental account- ing information disclosure in public company}

Suggestions on how to perfect the task of disclosing environmental accounting information in China are put forward.

\subsection{Make environmental accounting standard}

Make environmental accounting standards and set up accounting system according to current accounting standards. Clarify environment project confirmation, accounting and disclosure principle and specify environmental accounting information disclosure standard. Prevent short-term behavior of related enterprise or departments and guarantee standardization of environmental accounting work at the same time. Therefore, it makes accounting system is in accordance with accounting standards stipulated by the relevant designed principles and makes the environmental accounting information disclosure in listed companies has maneuverability to master by the accounting personnel easy.

\subsection{Strengthen audit of environmental accounting in- formation disclosure}

The current environmental accounting information disclosure audit work should be combined with the actual situation in our country at present. Auditing department should implement the audit investigation to determine whether there is a fraud case and whether carry out environmental policy, principles and ideas effectively, rather than just an environmental report of empty slogan in the process of developing and executing environmental protection laws and regulations. Project that enterprises implement must be consistent with the relevant national industrial policy on the environment protection, the power saving and the sustainable development. Relevant data must be true and reliable and pollutant emissions or governance should be consistent with the all environmental protection department know in business environmental performance disclosure. Environmental accounting information audit not only can protect information users' benefit, but can also guide enterprise, disclose environmental accounting information effectively, standardize market environment information disclosure.

\subsection{Improve accounting personnel professional quality}

Environmental accounting is gathering accounting, environment, ecological economics, sustainable development etc. many subjects penetrating into each other as a whole of application discipline. In the process of concrete application, multi-discipline principles, methods and means must be used, especially for some very professional disciplines such as the environment, biology, etc. Enterprise accounting people should still grasp sufficient environmental science knowledge as well as management knowledge except must have rich financial knowledge and experience. In order to improve the ability and the quality of accounting personnel and make them enable to complete environment accounting information disclosure work, environmental accounting knowledge trainings must be carried on to accounting personnel to update their traditional knowledge structure.

\section{Conclusion}

Serious environmental problems restrict economic development and social progress in the very great degree, while enterprise production and operating activities is one of the most important reasons that lead to environmental pollution. However, traditional financial accounting is lack of measurement of enterprise environmental resources, environmental responsibility and environmental costs and confirmation of enterprise environmental gains or losses, which cannot adapt to growing enterprise environmental activities. The establishment of environmental accounting and environmental information disclosure system is imperative.

\section{References}

[1]Chris J.van Staden, Jill Hooks.A comprehensive comparison of corporate environmental reporting and responsiveness[J].The British Accounting Review,39 (2009).

[2]Joshua Graff Zivin,Matthew Neidell.Days of haze.Environmental information disclosure and intertemporal avoidance behavior[J].Journal of Environmental Economics and Management,58 (2009).

[3]Xian bing Liu, V.Anbumozhi: Determinant factors of corporate environmental information disclosure, an empirical study of Chinese listed companies[J]. Journal of Cleaner Production ,17 (2009) 593-600.

[4]Jingjing He.Environmental accounting information disclosure of listed companies in our country [J].Accounting Friends,2011,(32).

[5]Jing Sun.Present situation analysis of environmental information disclosure of listed companies in electric power industry $[\mathrm{J}]$. Chinese township enterprises accounting, 2011, (9).

[6]Yuying Wang. Problems and countermeasures research on environmental accounting information disclosure of listed companies in China [J]. Ecurities and futures of China,2011,(8).

[7]Haitao Cheng. Research on accounting information disclosure system of listed companies in China [J] Value engineering,2011(15):90-93.

[8]Hong Wang. Study on environmental accounting information disclosure in public companies [J] Chinese market,2011(44):56-57. 